\title{
The effect of acid peptic digestion on free and tissue-bound cobalamins
}

\author{
BY J. F. ADAMS, ELIZABETH H. KENNEDY, \\ J. THOMSON AND J. WILLIAMSON \\ Southern General Hospital, Glasgow \\ (Received 22 fune 1967-Accepted 2 I September 1967)
}

\begin{abstract}
I. The extent of liberation of radioactive cobalamin in rabbit tissues incubated with acid and pepsin was evaluated by bag dialysis.

2. Between a half and two-thirds of the cobalamin-probably hydroxocobalamin-was dialysable after acid pepsin treatment and this process may be a factor in the absorption of cobalamins from foods.

3. Studies of pure cobalamin solutions at different concentrations gave apparently anomalous results, which may have been due to the adherence of cobalamin to the dialysis membrane. Measurement of the amount adherent to the membrane is an important factor in dialysis studies with cobalamins.
\end{abstract}

The absorption by man of cobalamins from food is believed to be mediated by the intrinsic factor mechanism. Cobalamins in foodstuffs are not free, but are bound to protein; it is probable that the first stage of absorption involves rupture of the cobalamin-food protein bond and binding of the freed cobalamin to intrinsic factor. As intrinsic factor is secreted in the gastric juice, these processes probably take place in the stomach. The mechanisms, however, are not clear. Observations on the in vitro liberation of tissue-bound cobalamins by acid and pepsin, which we report here, may have a bearing on these mechanisms. In addition we record relevant observations on free cyanocobalamin and hydroxocobalamin.

\section{EXPERIMENTAL}

Healthy Dutch rabbits weighing about $3 \mathrm{~kg}$ were obtained from the Veterinary School, University of Glasgow, and given a diet of pellets containing white fish meal $10 \%$, grass $20 \%$, bran $40 \%$, ground oats $12 \%$ and middlings $18 \%$, water ad lib. and supplements of greens and hay. The animals were given a single subcutaneous dose of 4-6 $\left.\mu \mathrm{g}\left(4^{0}-60 \mu \mathrm{c}\right){ }^{57} \mathrm{Co}\right]$ hydroxocobalamin and $5^{-6}$ weeks later were killed by injection of air into the heart. The skeletal muscle, liver and kidneys were removed, weighed and stored at $-20^{\circ}$. Thawed, sliced tissues were homogenized with distilled water in a Waring Blendor at approximately $\mathbf{1}_{5} 000 \mathrm{rev} / \mathrm{min}$ for $20 \mathrm{~min}$. About half of each homogenate was dispensed in $4 \mathrm{ml}$ portions in plastic tubes and stored at $-20^{\circ}$. The remainder was divided into $20 \mathrm{ml}$ portions in glass screw-capped bottles and heated at $15 \mathrm{lb} / \mathrm{in}^{2}$ for $20 \mathrm{~min}$; after cooling, the cooked tissues were pooled, homogenized without the addition of water and dispensed in $4 \mathrm{ml}$ portions in plastic tubes and stored at $-20^{\circ}$. In the studies reported here the muscle and liver homogenates were made from tissues of one animal and the kidney homogenate from tissues 
of another. The final concentrations of the homogenates were: muscle $0.20 \mathrm{~g} / \mathrm{ml}$, liver $0.12 \mathrm{~g} / \mathrm{ml}$ and kidney $0.032 \mathrm{~g} / \mathrm{ml}$.

The samples were transferred to glass boiling tubes and the total volume was made up to $10 \mathrm{ml}$ by the addition of $4 \mathrm{mlo} \cdot \mathrm{I} \mathrm{N}$-hydrochloric acid, $2 \mathrm{ml}$ freshly prepared $2.5 \%$ pepsin solution (Crystallized Pepsin; Armour Ltd) and water as required. The radioactivity was measured and the samples were incubated at $37^{\circ}$ for $\mathrm{I} h$. They were then transferred to dialysis bags and dialysed against tap water for $24 \mathrm{~h}$. The radioactivity remaining in the boiling tubes was measured and subtracted from the counts before incubation to obtain the value before dialysis. After dialysis the radioactivity in the bag and contents was measured. The bag was then emptied, split longitudinally and washed under running tap water, and the radioactivity of the washed bag was measured. The same procedure was followed and the same volumes and concentration. of reagents were used in the studies of solutions of radioactive hydroxocobalamin ar cyanocobalamin obtained from the Radiochemical Centre, Amersham. Each exper a as carried out in duplicate.

Dialysis bags were prepared by knotting one end of a suitable length of well-soaked cellophane tubing of circumference $5.7 \mathrm{~cm}$; the pore size of this tubing, obtained from Viscora S.A., Paris, was not greater than $25 \AA$. The dialysis bath contained $3^{61 .}$ water and the inflow and outflow during dialysis was $0.751 . / \mathrm{min}$. The bath temperature was $7-8^{\circ}$.

Radioactivity was measured in a well-type scintillation counter, IDL tvpe $66_{3}$, with a thallium-activated sodium iodide crystal $5.5 \mathrm{~cm}$ in diameter and 6, deep shielded by $10 \mathrm{~cm}$ lead and connected to an IDL I 700 automatic scaler. The geometry of the system was such that no correction of count rates for volumes: "er ${ }_{5} 5 \mathrm{ml}$ was required. The counting error ranged from $\pm 1 \%$ to $\pm 5 \%$.

\section{RESULTS}

The results are summarized in Table $\mathrm{I}$.

The $\mathrm{pH}$, measured electrometrically, of preparations with water or with water and pepsin solution, ranged from $6 \cdot 0$ to $7 \cdot \mathrm{I}$, with acid and water from $\mathrm{r} \cdot 4$ to $\mathrm{I} \cdot 8$ and with acid and pepsin solutions from $I \cdot 5$ to $2 \cdot 0$.

The activity of the tissues, determined by microbiological assay with Euglena gracilis (Hutner, Bach \& Ross, I956), was raw muscle $0.036 \mu \mathrm{g}$, cooked muscle 0.064 $\mu \mathrm{g}$, raw liver $0.147 \mu \mathrm{g}$, cooked liver $0.236 \mu \mathrm{g}$, raw kidney $0^{\circ} 128 \mu \mathrm{g}$, cooked kidney ०. I30 $\mu \mathrm{g}$, all per $4 \mathrm{ml}$ homogenate.

\section{DISCUSSION}

The striking feature of the results is the marked decrease in amounts of radioactive material retained after incubation with acid and pepsin followed by dialysis. All tissues, raw or cooked, were affected, and in this respect our results differ from those reported by Reizenstein (1959). Working with rooster muscle and calf and pig liver and kidney, he found that peptic digestion at acid $\mathrm{pH}$ liberated considerable proportions of radioactive material from liver and kidney homogenates but not frum skeletal muscle 
Table $\mathrm{I}$. Percentage cobalamin retained in bag after dialysis of homogenized rabbit tissues and of vitamin $B_{12}$ solutions

(Mean values and standard deviations. Uncorrected values are the percentages of the original radioactivity found in both bag and contents at the end of dialysis; corrected values are the percentages of the original radioactivity after dialysis when allowance has been made for the amount of radioactivity adherent to the dialysis bag after washing)

\section{Material in} dialysis bag

Muscle: raw

Muscle: cooked

Kidney: raw

Kidney: cooked

Liver: raw

Liver: cooked

Cyanocobalamin : $0.02 \mu \mathrm{g} / \mathrm{ml}$

Cyanocobalamin: $100 \mu \mathrm{g} / \mathrm{ml}$

Hydroxocobalamin: $0.02 \mu \mathrm{g} / \mathrm{ml}$

Hydroxocobalamin: $100 \mu \mathrm{g} / \mathrm{ml}$

$$
\begin{gathered}
\text { Treatment of material } \\
\text { (see p. I I I) }
\end{gathered}
$$

None

Pepsin

Acid

Acid and pepsin

None

Pepsin

Acid

Acid and pepsin

None

Pepsin

Acid

Acid and pepsin

None

Pepsin

Acid

Acid and pepsin

None

Pepsin

Acid

Acid and pepsin

None

Pepsin

Acid

Acid and pepsin

None

Acid and pepsin

None

Acid and pepsin

None

Acid and pepsin

None

Acid and pepsin
Mean percentage cobalamin

\begin{tabular}{|c|c|}
\hline Uncorrected & Corrected \\
\hline $\begin{array}{l}79 \cdot 4 \pm 3 \cdot 9 \\
69 \cdot 7 \pm 7 \cdot 0\end{array}$ & $\begin{array}{l}71 \cdot 5 \pm 3 \cdot 5 \\
66 \cdot 1 \pm 5 \cdot 4\end{array}$ \\
\hline $\begin{array}{l}59 \cdot 1 \pm 1 \cdot 3 \\
39 \cdot 1 \pm 8 \cdot 8\end{array}$ & $\begin{array}{l}54.4 \pm 1 \cdot 2 \\
33 \cdot 9 \pm 9 \cdot 5\end{array}$ \\
\hline $\begin{array}{l}74 \cdot 5 \pm 5 \cdot 2 \\
72 \cdot 8 \pm 0 \cdot 8 \\
66 \cdot 9 \pm 6 \cdot 4 \\
52 \cdot 3 \pm 8 \cdot 1\end{array}$ & $\begin{array}{l}65 \cdot 6 \pm 7 \cdot 2 \\
59 \cdot 1 \pm 2 \cdot 9 \\
55 \cdot 5 \pm 0 \cdot 1 \\
46 \cdot 2 \pm 5 \cdot 8\end{array}$ \\
\hline $\begin{array}{l}85.4 \pm 5 \cdot 4 \\
80 \cdot 6 \pm 9 \cdot 0\end{array}$ & $\begin{array}{l}73.5 \pm 6.3 \\
58.6 \pm 3.5\end{array}$ \\
\hline $\begin{array}{l}71 \cdot 5 \pm 6 \cdot 0 \\
57 \cdot 3 \pm 4 \cdot 9\end{array}$ & $\begin{array}{l}56 \cdot 5 \pm 5 \cdot 9 \\
4 I \cdot 1 \pm 5 \cdot 6\end{array}$ \\
\hline $\begin{array}{l}75 \cdot 9 \pm 6 \cdot 2 \\
76 \cdot 5 \pm 4 \cdot 6\end{array}$ & $\begin{array}{l}57 \cdot 3 \pm 4.2 \\
59.2 \pm 1.6\end{array}$ \\
\hline $\begin{array}{l}57 \cdot 5 \pm 12 \cdot 0 \\
51.8 \pm 6 \cdot 5\end{array}$ & $\begin{array}{l}44 \cdot 1 \pm 0.3 \\
39 \cdot 5 \pm 0.7\end{array}$ \\
\hline $\begin{array}{l}84 \cdot 6 \pm 4 \cdot 6 \\
81 \cdot 5 \pm 3 \cdot 3\end{array}$ & $\begin{array}{l}76 \cdot 4 \pm 4 \cdot 8 \\
68 \cdot 2 \pm I \cdot 4\end{array}$ \\
\hline $\begin{array}{l}63 \cdot 6 \pm x \cdot 8 \\
47 \cdot 1 \pm 8 \cdot 8\end{array}$ & $\begin{array}{l}5 I \cdot 3 \pm 5 \cdot 0 \\
37 \cdot 8 \pm 4 \cdot 8\end{array}$ \\
\hline $\begin{array}{l}75 \cdot 0 \pm 9 \cdot 3 \\
72 \cdot 5 \pm 10 \cdot 7 \\
49 \cdot 3 \pm 5 \cdot 4 \\
40 \cdot 3 \pm 7 \cdot 1\end{array}$ & $\begin{array}{l}5 x \cdot 1 \pm 4 \cdot 3 \\
54 \cdot 9 \pm 3 \cdot 7 \\
30 \cdot 8 \pm 1 \cdot 9 \\
32 \cdot 8 \pm 2 \cdot 2\end{array}$ \\
\hline $\begin{array}{l}30.8 \pm 6.5 \\
27.5 \pm 7 \cdot 6\end{array}$ & $\begin{array}{l}20.5 \pm 5.5 \\
20.9 \pm 3.0\end{array}$ \\
\hline $\begin{array}{l}27 \cdot 1 \pm 7 \cdot 9 \\
26 \cdot 5 \pm 7 \cdot 2\end{array}$ & $\begin{array}{l}22.5 \pm 5.9 \\
23.5 \pm 5.7\end{array}$ \\
\hline $\begin{array}{l}44.0 \pm 16.9 \\
40.5 \pm 13.5\end{array}$ & $\begin{array}{l}2 I \cdot 9 \pm 8 \cdot 4 \\
22 \cdot 5 \pm 10 \cdot 3\end{array}$ \\
\hline $\begin{array}{l}12 \cdot 5 \pm 3 \cdot 8 \\
19 \cdot 8 \pm 3 \cdot 6\end{array}$ & $\begin{array}{r}9.8 \pm 2.5 \\
16.8 \pm 2.6\end{array}$ \\
\hline
\end{tabular}
retained

homogenates. It is possible that the differences in results from muscle homogenates may be related to the origin of the tissue; this point requires further study.

The importance of an acid $\mathrm{pH}$ in the in vitro liberation of cobalamins from meat has been established by Cooper \& Castle ( 1960$)$, and our results confirm their findings and show that peptic activity may also be a factor of some importance. The results of in vitro studies, however, are not always relevant to in vivo situations and the suggestion that peptic digestion may be important in absorption of food-bound cobalamins requires confirmation by in vivo studies.

The nature of the radioactive material in the tissues was not studied. It is known that 
the native cobalamin in rabbit liver is coenzyme $B_{12}$ (Toohey \& Barker 1961) and that injected hydroxocobalamin is converted in vivo into coenzyme $B_{12}$ (Uchino, Yagiri, Yoshimo, Kondo \& Wakisaka, I965). From this it seems probable that the radioactive material was coenzyme $B_{12}$ and that this would have been converted into hydroxocobalamin by photolysis during homogenization and other manipulations.

The pure cobalamin solutions of low concentrations were included as controls for the tissue studies, the concentrations approximating to those found in the tissues by microbiological assay. The higher concentrations were studied as a matter of interest and not because they had any relevance to the tissue studies. It is clear that incubation with acid and pepsin and alterations in concentration do not affect the percentage of cyanocobalamin retained after dialysis. The percentage of hydroxocobalamin retained is less at the higher concentration, and at this concentration incubation with acid and pepsin results in an increase in the percentage retained. In addition, the uncorrected values for both cobalamins show that at the lower concentration retention of hydroxocobalamin is greater than that of cyanocobalamin while the converse obtains at the higher concentrations. Some of these anomalies are resolved by the corrected values, all of which, with the exception of those for hydroxocobalamin in high concentration, are strikingly similar. This observation shows that the differences in uncorrected values are due to adherence of cobalamins to the dialysis tubing, and we suspect that this may be related to the fact that cyanocobalamin is neutral and hydroxocobalamin is basic. This, however, is unlikely to be the sole factor, if one at all, in the curious behaviour of hydroxocobalamin in the higher concentration and we cannot account for this. One point which emerges clearly from the studies with cobalamin solutions is the importance of measuring the amount of material adherent to the dialysis tubing and taking this into account in evaluating results.

We are grateful to Merck Sharp and Dohme Ltd for supplies of radioactive cobalamins, to Dr A. C. Kennedy, Royal Infirmary, Glasgow, for supplies of dialysis tubing and to Professor T. Ferguson Rodger for facilities in his Department. Two of us (J. F. A. and E. H. K.) acknowledge with thanks a grant from the Secretary of State on the advice of the Advisory Committee for Medical Research.

\section{REFERENCES}

Cooper, B. A. \& Castle, W. B. (1960). F. clint. Invest. 39, 199.

Hutner, S. H., Bach, M. K. \& Ross, G. I. M. (1956). F. Protozool. 3, гог.

Reizenstein, P. G. (1959). Acta med. scand. 165, 48 I,

Toohey, J. I. \& Barker, H. A. (I96I). F. biol. Chem. 236, 560.

Uchino, H., Yagiri, Y., Yoshimo, T., Kondo, M. \& Wakisaka, G. (1965). Nature, Lond. 205, I 76. 